\title{
DISTRIBUTION PATTERNS OF PTILIUM CRISTA-CASTRENSIS (BRYOPHYTA, HYPNACEAE) IN THE EAST EUROPEAN PLAIN AND EASTERN FENNOSCANDIA
}

\author{
Sergey Yu. Popov*, Yulia A. Makukha \\ Lomonosov Moscow State University, Russia \\ *e-mail:s_yu_popov@rambler.ru
}

Received: 04.06.2018. Revised: 12.01.2019. Accepted: 15.01.2019.

\begin{abstract}
Ptilium crista-castrensis is one of the most common moss species in the forest zone. It is dominant in the moss layer of the blueberry and cowberry forests. At least with low abundance, it occurs almost in every forest type and mires. In addition, it is a component of the moss layer in tundra. We compiled the published annotated lists of regional bryophyte floras into a generalised dataset. We then created a map of the $P$. crista-castrensis model range using the kriging method. We included data from 179 locations, with data points in 39 Protected Areas. We determined climatic preferences of the species by comparing the species occurrence and climatic factors on locations. The comparison of the created model map with the map of vegetation zones allowed us to analyse the spatial distribution of $P$. crista-castrensis. We could demonstrate a sharp decrease of $P$. crista-castrensis abundance at the borders of the forest and steppe zones. By the range boundaries, this moss is a rarely occurring species, where it grows exclusively in limited pine forest patches. This species is completely lacking in the steppe zone. Its abundance has maximal values in the northern taiga subzone considered as the climatic optimum of $P$. crista-castrensis. In the forest zone, the occurrence of $P$. crista-castrensis varies from sporadically to commonly. At the northern and southern borders of the forest zone, the species occurrence is characterised as rare. A too low average temperature and precipitation are unfavourable for P. crista-castrensis in the north of the study area. At the same time, a too high temperature and too low precipitation and humidity have the same effect in the south of the study area.
\end{abstract}

Key words: biogeography, distribution range, geostatistical techniques, species' climatic optimum, species' occurrence

Ptilium crista-castrensis (Hedw.) De Not. is a feather moss. It is a widely distributed moss in boreal ecosystems. This species grows together with other bryophyte species of boreal spruce forests, like Pleurozium schreberi (Brid.) Mitt. and Hylocomium splendens (Hedw.) Schimp. (Bonan \& Shugart, 1989; Esseen et al., 1997). Ptilium cristacastrensis occurs predominantly in the forest zone, rarer in tundra. Spruce forests of the Myrtillus-type and forested mires of the taiga zone are the most typical plant communities with $P$. crista-castrensis participation. In Europe, it occurs predominantly in spruce forests and rarely in heathlands (association Vaccinio-Callunetum vulgaris) (Dierssen, 2001). This moss inhabits frequently the forest soil, along the tree trunk bases, on rock-covered cliffs and boulders, in meadows. To the south of the taiga zone this moss is considered as a rare species (Kurnaev, 1980; Ignatov \& Ignatova, 2004; Belyaeva \& Neshataeva, 2017). Ptilium cristacastrensis can easily be identified in the field. Its ecology is very well known.

The geographic distribution of Ptilium cristacastrensis is also well known. This species is dis- tributed in Western and Central Europe, European Russia, Caucasus, Urals, and in the Far East (Ignatov \& Ignatova, 2004). There are many recent publications on regional bryophyte floras. It allows us to generalise these data and identify the range zone of $P$. crista-castrensis. The development of GIS-based spatial analysis methods has enabled attaining this goal. Moreover, modern GIS approaches provide the tools for studying climatic and other biogeographic patterns of species distribution (Mateo et al., 2013).

The approach to the current study of the $P$. crista-castrensis distribution is based on Geostatistical techniques. In this paper, we aimed 1) to close the gap in the $P$. crista-castrensis biogeography in the East European Plain and Eastern Fennoscandia (EEPEF); 2) to visualise its distribution range; 3) to elucidate the influence of climatic factors on the species spatial distribution.

\section{Material and Methods}

We have analysed the published annotated lists of bryophyte floras of different regions (European Russia, Baltic countries, Ukraine, 
Belarus, Moldova) to study the distribution of Ptilium crista-castrensis (Fig. 1). Some dots have been chosen outside the area of interest (e.g. Romania, Poland, Kazakhstan, Caucasus, the eastern mountainside of the Urals) to correct possible errors of extrapolation at the area boundaries (Demyanov \& Savelyeva, 2010; Popov, 2016). We applied the basic principles of area modelling, using geostatistics methods and analysing the distribution range of the moss species by using the kriging method published previously (Popov, 2017).

After generalisation of all available data, we evaluated the Ptilium crista-castrensis occurrence using the following six-point scale of species occurrence: 0 - absent ( 0 records), 1 - very rare (1-2 records), 2 - rare (3-7 records), 3 - sporadic (more than seven records, but not everywhere), 4 - frequent (common species, but sometimes not found in suitable phytocoenoses), 5 - common (common and coenotically active species within the study area). According to this scale, we created a continuous coverage map with a resolution of $10 \mathrm{~km}$ per 1 pixel using the kriging method according to Demyanov \& Savelyeva (2010).

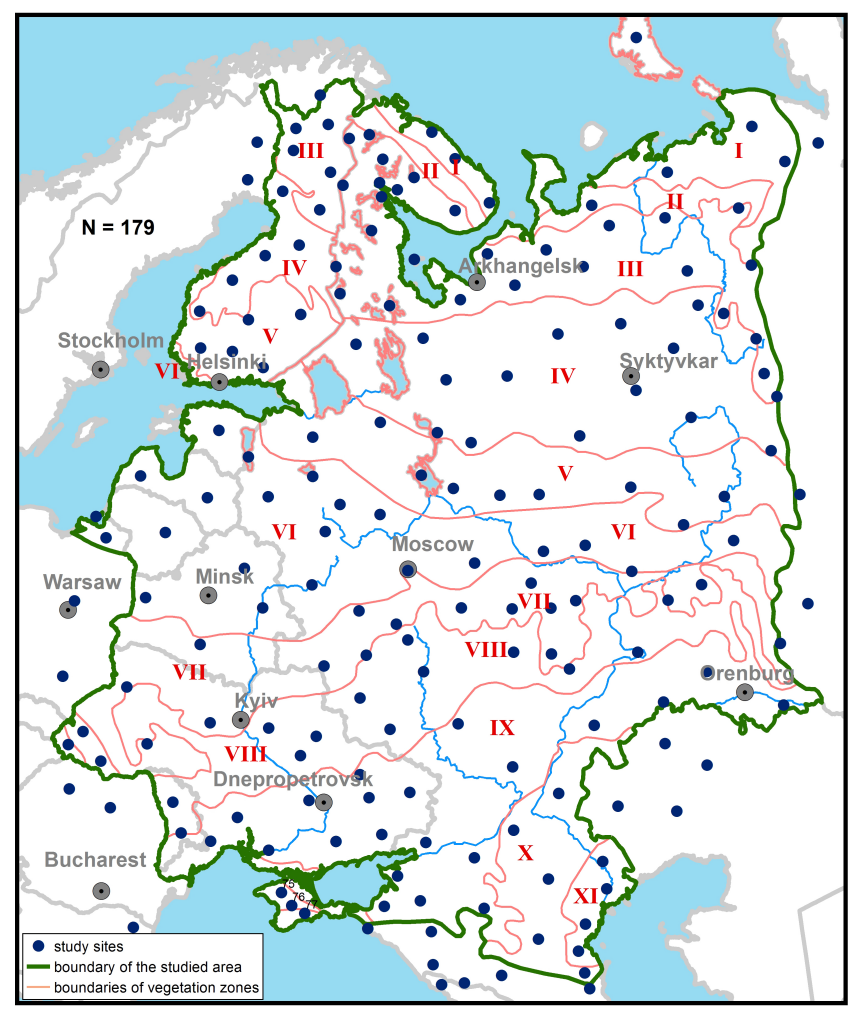

Fig. 1. Vegetation zones with indicated locations used in this study: I - tundra; II -forest-tundra; III - northern taiga; IV - middle taiga; V - southern taiga; VI - mixed forests; VII - broad-leaved forests; VIII - forest-steppe; IX - steppe; X - semi-desert; XI - desert. Boundaries of vegetation zones are given according to Ahti et al. (1968) and Kurnaev (1973).
In total, we used data from 179 locations to create a continuous coverage map (Fig. 1), Of which 39 are in the following Protected Areas: Shichengsky Landscape Sanctuary, Basegi State Nature Reserve, Bolshaya Kokshaga State Nature Reserve, Bryansky Les State Nature Reserve, Caucasian State Nature Biosphere Reserve, Central Forest State Nature Biosphere Reserve, Darwin State Nature Reserve, Denezhkin Kamen State Nature Reserve, Kandalakshsa State Nature Reserve, Kerzhensky State Nature Reserve, Kivach State Nature Reserve, Kologrivsky Les State Nature Reserve, Kostomuksha State Nature Reserve, Lapland State Nature Reserve, Mordovia State Nature Reserve, Niznesvirsky State Nature Reserve, Oksky State Nature Reserve, Orenburg State Nature Reserve, Pasvik State Reserve, Pechora-Ilych State Nature Reserve, Pinega State Nature Reserve, Prisursky State Nature Reserve, Privolzhskaya Lesostep' State Nature Reserve, Shulgan-Tash State Nature Reserve, Teberda State Nature Reserve, Vishersky State Nature Reserve, Visimsky State Nature Biosphere Reserve, Vitim State Nature Reserve, Volzhsko-Kamsky State Nature Biosphere Reserve, Voronezh State Nature Reserve, Zhiguli State Nature Biosphere Reserve, Iremel Nature Park, Kulikovo Pole Nature-Historical Reserve, Losiny Ostrov National Park, Narew National Park, Russky Sever National Park, National Park «Smolny», Vodlozersky National Park, Yugyd Va National Park. References to published sources with annotated species lists for 179 locations are listed in Popov (2018). In this paper, we could add two more locations (Silaeva et al., 2011; Chernyadyeva et al., 2017).

The verification of the continuous coverage was performed using a cross-validation method with SAGA GIS software. In geostatistics, the index of cross-validation quality is the coefficient of determination $\left(\mathrm{R}^{2}\right)$ (Demyanov \& Savelyeva, 2010). In this study, this indicator value was 0.912 .

In our study, we also used continuous coverage of climatic factors. We used the dataset proposed by the authors of the WORLDCLIM program (BIOCLIM, 2009). In total, we used 23 climatic variables, including monthly temperature (seven variables), annual temperature (one variable), annual precipitation (one variable), monthly precipitation (seven variables), and relative humidity (seven variables), extracted for April - October. For our study, we selected only months of the vegetation season. The coverage of climatic factors and species occurrence were combined into a single spatial database, which has been transformed into the table consisting of 24 variables (23 climatic factors and one species' occurrence) and 49557 cases (number of pixels). A correlation analysis was per- 
formed using the Statistica 6.0 software. The coverages were created and verified using SAGA software. The intersection of vector layers and areas' calculation were performed using the ArcGIS software. All these techniques were explained in Popov (2017).

\section{Results and Discussion}

Fig. 2 shows the model map of the P. cristacastrensis' distribution range. Evidently, the area of the common species occurrence («com») coincides approximately with the northern taiga subzone. The occurrence level of $P$. crista-castrensis decreased to the south and to the north of this zone. In general, the frequent occurrence area coincides with the taiga zone. This is not surprising, because $P$. cristacastrensis is one of the dominant species in coniferous forests (Esseen et al., 1997; Ignatov \& Ignatova, 2004). This species is rare in the tundra zone (e.g. in the Kola Peninsula). Ptilium crista-castrensis is also present in the mainland tundra, having, however, a low abundance. The species completely disappears by the northern limit of the study area. For example, there are only a few locations with P. crista-castrensis in the Yamal Peninsula, and it is completely absent on Novaya Zemlya (Afonina \& Chernyadyeva, 1995; Chernyadyeva, 2001). Outside the study area, the distribution of spruce forests coincides with the $P$. crista-castrensis distribution in Scandinavia and in the mountains of continental Europe (Söderström, 1998; Dierssen, 2001; GBIF, 2018). This fact is in good agreement with its higher occurrence in the northern taiga of Russia (Fig. 2).

In the southern part of the study area, $P$. cristacastrensis has a sporadic occurrence in the vegetation zones of mixed forests and broad-leaved forests. The species is rare in the forest-steppe zone. Further, $P$. crista-castrensis disappears in the vegetation cover in the northern steppe subzone (Fig. 2). The species inhabits sporadically distributed and limited pine plantations in the steppe and in forest-steppe vegetation zones (Gapon, 1997; Popova, 2002).

The occurrence of $P$. crista-castrensis depends upon the autumn - summer precipitation and the relative air humidity (Table 1 ). Annual precipitation produces a moderate effect. The temperature factor looks to be the most important for P. crista-castrensis. It includes both the annual temperature and the monthly temperature during the vegetation season (Table 1). We could state that $P$. crista-castrensis's optimum is in the northern taiga (Fig. 2), taking into account that according to biogeographic principles (Grinnell, 1917), the climatic optimum of a species is in the area where it has the maximal occurrence.

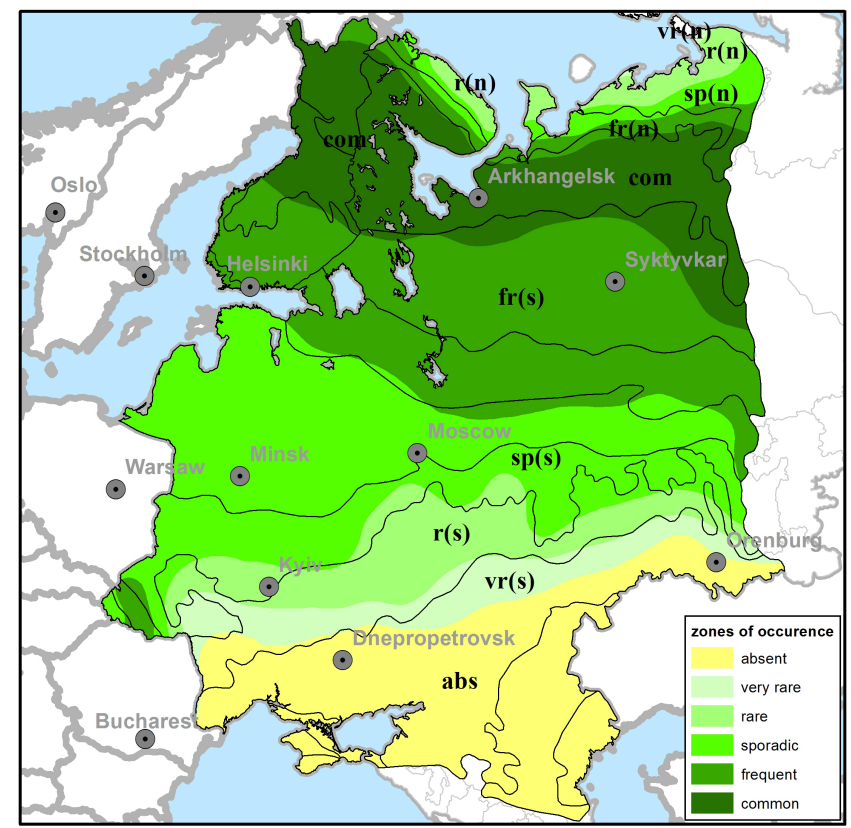

Fig. 2. Model range of Ptilium crista-castrensis. Black lines indicate the boundaries of vegetation zones. Occurrence zones: abs - species is absent; vr - species is very rare; $\mathbf{r}$ - species is rare; $\mathbf{s p ~ - ~ s p e c i e s ~ i s ~ s p o r a d i c ; ~ f r ~ - ~ s p e c i e s ~ i s ~}$ frequent; com - species is common. The letters (n) and (s) placed after the abbreviation of the occurrence zones indicate respectively the relative north and south of the study area.

Table 1. The Spearman correlation coefficient between values of climatic factors and species occurrence. Values of $r>$ 0.5 in absolute value are highlighted in bold. All values are statistically significant $(\mathrm{p}<0.05)$

\begin{tabular}{|c|c|c|}
\hline № & Climatic factor & Correlation coefficient \\
\hline 1 & amt & $\mathbf{- 0 . 8 2}$ \\
\hline 2 & pr04 & -0.02 \\
\hline 3 & pr05 & 0.06 \\
\hline 4 & pr06 & 0.36 \\
\hline 5 & pr07 & 0.13 \\
\hline 6 & pr08 & $\mathbf{0 . 7 2}$ \\
\hline 7 & pr09 & $\mathbf{0 . 7 9}$ \\
\hline 8 & pr10 & $\mathbf{0 . 7 5}$ \\
\hline 9 & pr_a & 0.40 \\
\hline 10 & reh04 & 0.38 \\
\hline 11 & reh05 & 0.45 \\
\hline 12 & reh06 & 0.36 \\
\hline 13 & reh07 & $\mathbf{0 . 5 3}$ \\
\hline 14 & reh08 & $\mathbf{0 . 7 5}$ \\
\hline 15 & reh09 & $\mathbf{0 . 8 0}$ \\
\hline 16 & reh10 & $\mathbf{0 . 8 4}$ \\
\hline 17 & tm04 & $\mathbf{- 0 . 8 6}$ \\
\hline 18 & tm05 & $\mathbf{- 0 . 8 7}$ \\
\hline 19 & tm06 & $\mathbf{- 0 . 8 6}$ \\
\hline 20 & tm07 & $\mathbf{- 0 . 8 2}$ \\
\hline 21 & tm08 & $\mathbf{- 0 . 8 7}$ \\
\hline 22 & tm09 & $\mathbf{- 0 . 8 7}$ \\
\hline 23 & tm10 & $\mathbf{- 0 . 7 9}$ \\
\hline
\end{tabular}

Note: Climatic factors: amt - annual amount of precipitation; pr01 - pr12 - monthly amount of precipitation in January - December; $\mathbf{p r}_{-} \mathbf{a}$ - average of annual precipitation; reh4 - reh10 - relative humidity in April - October; tm04 - tm10 - monthly average temperature in April - October. 
Table 2 shows the climatic optimum and pessimum values for $P$. crista-castrensis in the study area. According to Table 2 (column «com»), the species requires an average annual temperature of about $-1^{\circ} \mathrm{C}$ and a monthly temperature of $+11^{\circ} \mathrm{C}$ to $+15^{\circ} \mathrm{C}$ during the summer period. In other words, apparently $P$. crista-castrensis is better adapted to areas with cool summers. However, this species requires a relatively high humidity (ca. $80 \%$ ) in the summer period (Table 2). The climatic conditions of the northern taiga meet these requirements to the greatest extent (Kurnaev, 1973).

A low temperature and precipitation are the main unfavourable conditions for Ptilium cristacastrensis in the north. On the contrary, a high temperature, low precipitation and low humidity restrict its spread to the south (Table 2). If the average annual temperature exceeds $+7^{\circ} \mathrm{C}$ and the annual rainfall is less than $500 \mathrm{~mm}, P$. crista-castrensis is disappearing. Thus, the distribution pattern of $P$. crista-castrensis corresponds to Shelford's rule (Tolmachev, 1974; Vtorov \& Drozdov, 2001). The conducted analysis showed the maximal and minimal values of the limiting factors (Table 2). These are considered to be of the greatest impact on the distribution of $P$. crista-castrensis. In Table 1, these factors have correlation coefficients over 0.5 (absolute values).

The model distribution map clearly showed that the major part of the EEPEF area is located in the southern parts of the frequent and sporadic occurrence zones (Table 3 ). The zone of common occurrence occupies only $15.3 \%$ of the total area (Table 3). The zones of rare and very rare occurrence (both in the north and in south parts of the study area) have very small percentage values of the study area (Table 3 ). Accordingly, the species is quite widespread in the central part of the study area. Then, it gradually disappears at the borders both in the north and in the south. The absence zone covers $17.3 \%$ of the EEPEF area (Table 3 ).

Table 2. Average values of climatic factors in the occurrence zones of Ptilium crista-castrensis

\begin{tabular}{|c|c|c|c|c|c|c|c|c|c|c|c|}
\hline \multirow{2}{*}{ Climatic factor } & \multicolumn{10}{|c|}{ Occurrence zones } & \multirow{2}{*}{ Average } \\
\hline & abs & $\operatorname{vr}(\mathrm{s})$ & $\mathrm{r}(\mathrm{s})$ & $\mathrm{sp}(\mathrm{s})$ & $\mathrm{fr}(\mathrm{s})$ & com & $\operatorname{fr}(n)$ & $\mathrm{sp}(\mathrm{n})$ & $\mathrm{r}(\mathrm{n})$ & $\operatorname{vr}(n)$ & \\
\hline amt & 8.7 & 6.3 & 5.6 & 4.9 & 2.0 & -0.9 & -2.3 & -3.7 & -4.2 & -6.2 & 3.7 \\
\hline pr04 & 31.7 & 35.7 & 38.5 & 38.6 & 37.3 & 31.9 & 26.4 & 24.9 & 22.8 & 19.9 & 35.1 \\
\hline pr05 & 40.7 & 44.0 & 48.3 & 50.1 & 48.4 & 41.8 & 35.0 & 33.8 & 30.7 & 28.4 & 45.3 \\
\hline pr06 & 50.5 & 59.6 & 65.3 & 69.0 & 64.8 & 57.4 & 48.6 & 46.2 & 41.6 & 36.3 & 60.9 \\
\hline pr07 & 46.2 & 62.8 & 75.0 & 79.9 & 78.5 & 68.0 & 59.3 & 55.6 & 50.6 & 46.4 & 69.1 \\
\hline pr08 & 37.4 & 48.9 & 59.0 & 68.6 & 74.2 & 71.7 & 63.8 & 61.6 & 58.2 & 54.0 & 62.6 \\
\hline pr09 & 33.9 & 42.0 & 48.8 & 58.5 & 64.5 & 62.2 & 57.6 & 56.3 & 54.7 & 54.2 & 54.3 \\
\hline pr10 & 28.7 & 38.2 & 43.9 & 51.9 & 60.7 & 54.9 & 50.4 & 47.6 & 46.1 & 41.7 & 48.7 \\
\hline pr_a & 436.6 & 529.9 & 577.6 & 612.3 & 626.4 & 561.7 & 485.1 & 453.7 & 421.1 & 357.6 & 560.5 \\
\hline reh04 & 64.8 & 65.8 & 67.9 & 70.7 & 71.8 & 76.2 & 83.2 & 87.2 & 89.9 & 94.8 & 71.2 \\
\hline reh05 & 57.6 & 56.6 & 58.9 & 64.0 & 63.7 & 68.7 & 75.5 & 78.2 & 80.6 & 83.4 & 63.5 \\
\hline reh06 & 58.8 & 60.8 & 64.2 & 68.6 & 66.9 & 67.5 & 71.9 & 73.2 & 75.2 & 76.2 & 65.8 \\
\hline reh07 & 57.8 & 62.3 & 66.9 & 72.0 & 71.8 & 71.8 & 74.5 & 74.8 & 76.1 & 75.8 & 68.7 \\
\hline reh08 & 57.6 & 61.6 & 66.6 & 73.7 & 76.9 & 78.7 & 80.7 & 81.3 & 82.4 & 82.8 & 71.6 \\
\hline reh09 & 62.7 & 65.7 & 70.6 & 77.7 & 81.8 & 83.6 & 84.5 & 84.9 & 85.9 & 86.5 & 76.1 \\
\hline reh10 & 73.7 & 76.0 & 79.3 & 83.5 & 87.2 & 89.4 & 90.6 & 92.5 & 93.5 & 96.7 & 83.3 \\
\hline $\operatorname{tm} 04$ & 9.8 & 8.0 & 7.0 & 5.5 & 2.2 & -2.1 & -5.0 & -7.2 & -8.3 & -11.2 & 3.9 \\
\hline $\operatorname{tm} 05$ & 16.6 & 15.2 & 14.4 & 12.8 & 9.5 & 4.8 & 1.6 & -0.2 & -1.2 & -3.3 & 11.0 \\
\hline $\operatorname{tm} 06$ & 20.5 & 18.7 & 17.8 & 16.4 & 14.5 & 11.4 & 8.6 & 7.4 & 6.5 & 5.4 & 15.6 \\
\hline $\operatorname{tm} 07$ & 22.8 & 20.5 & 19.3 & 18.0 & 17.0 & 14.8 & 13.1 & 12.5 & 11.8 & 11.3 & 18.0 \\
\hline $\operatorname{tm} 08$ & 21.6 & 19.3 & 18.1 & 16.6 & 14.6 & 12.1 & 10.6 & 9.9 & 9.4 & 8.6 & 16.2 \\
\hline $\operatorname{tm} 09$ & 16.3 & 14.0 & 12.8 & 11.6 & 9.1 & 6.8 & 5.8 & 5.2 & 4.9 & 4.0 & 11.0 \\
\hline $\operatorname{tm} 10$ & 8.8 & 6.6 & 5.9 & 5.4 & 2.4 & -0.2 & -1.4 & -2.6 & -2.9 & -5.0 & 4.1 \\
\hline
\end{tabular}

Note: see Fig. 2 for abbreviations of the occurrence zones. 
Table 3. Occurrence zones of Ptilium crista-castrensis by vegetation zones, $\mathrm{km}^{2}$

\begin{tabular}{|l|c|c|c|c|c|c|c|}
\hline Vegetation zone & abs & vr & r & sp & fr & com & Total \\
\hline Tundra & - & 3418.4 & 92822.8 & 65335.1 & 16161.8 & 14020.1 & 191758.2 \\
\hline Forest-tundra & - & - & 126.1 & 28440.5 & 59630.6 & 13894.7 & 102091.9 \\
\hline Northern taiga & - & - & - & - & 31146.4 & 519581.3 & 550727.7 \\
\hline Middle taiga & - & - & - & - & 545491.0 & 202528.6 & 748019.6 \\
\hline Southern taiga & - & - & - & 31060.0 & 502545.3 & 6368.5 & 539973.8 \\
\hline Mixed forests & - & - & - & 742694.8 & 71629.5 & - & 814324.3 \\
\hline Deciduous forests & 8027.5 & 27955.9 & 92921.4 & 382382.4 & 5863.3 & - & 517150.5 \\
\hline Forest-steppe & 39467.3 & 103734.0 & 307901.5 & 71600.1 & - & - & 522702.9 \\
\hline Steppe & 549057.8 & 145742.1 & 11809.6 & 1973.2 & - & - & 708582.7 \\
\hline Semi-desert & 204708.3 & 51.7 & - & - & - & - & 204760 \\
\hline Desert & 54863.8 & - & - & - & - & - & 54863.8 \\
\hline Total, km & 856124.7 & 280902.2 & 505581.5 & 1323486.0 & 1232468.1 & 756393.1 & 4954955.4 \\
\hline Total, $\%$ & 17.3 & 5.7 & 10.2 & 26.7 & 24.9 & 15.3 & 100 \\
\hline
\end{tabular}

\section{Conclusions}

The abundance of Ptilium crista-castrensis is correlated with the occurrence of coniferous forests (taiga zone) in such a large area as EEPEF, where 11 vegetation zones occur (Fig. 1). The species' occurrence is maximal in the northern taiga. This region is characterised by a specific climatic optimum for $P$. crista-castrensis, considered as an average annual temperature of about $-1{ }^{\circ} \mathrm{C}$ and an average monthly humidity of about $80 \%$. In the forest zone, the P. cristacastrensis occurrence varied from sporadically to commonly. This species is rare both to the north and to the south of the forest zone.

\section{References}

Afonina O.M., Chernyadyeva I.V. 1995. Mosses of the Russian Arctic: check-list and bibliography. Arctoa 5: 99142. DOI: $10.15298 /$ arctoa.05.07

Ahti T., Hämet-Ahti L., Jalas J. 1968. Vegetation zones and their sections in northwestern Europe. Annales Botanici Fennici 5(3): 169-211.

Belyaeva N.G., Neshataeva V.Yu. 2017. The community diversity of Nemoral birch forests of South-West of Moscow Region. Phytodiversity of Eastern Europe 11(1): 63-73. [In Russian]

BIOCLIM. 2009. BIOCLIM project. Modelling Sequential Biosphere Systems under Climate Change for Radioactive Waste Disposal. Available from: http://www. andra.fr/bioclim

Bonan G.B., Shugart H.H. 1989. Environmental factors and ecological processes in boreal forests. Annual Review of Ecology and Systematics 20: 1-28. DOI: 10.1146/annurev.es.20.110189.000245

Chernyadyeva I.V. 2001. Moss flora of Yamal Peninsula (West Siberian Arctic). Arctoa 10: 121-150. DOI: 10.15298/arctoa.10.13

Chernyadyeva I.V., Mežaka A., Grishutkin O.G., Potemkin A.D. 2017. Bryophytes of the Mordovia State Nature
Reserve (an annotated species list). Moscow: Commision of RAS on biodiversity conservation; IPEE RAS. 30 p. [In Russian]

Demyanov V.V., Savelyeva E.A. 2010. Geostatistics: Theory and Practice, Moscow: Nauka. 327 p. [In Russian]

Dierssen K. 2001. Distribution, ecological amplitude and phytosociological characterization of European bryophytes. Bryophytorum Bibliotheca 56: 1-289.

Esseen P.A., Ehnström B., Ericson L., Sjöberg K. 1997. Boreal forests. Ecological Bulletin 46: 16-47.

GBIF. 2018. Global Biodiversity Information Facility. Available from: https://www.gbif.org/

Gapon S.V. 1997. List of mosses of Ukrainian forest-steppe. Poltava: Publisher of the Poltava State Pedagogical Institute. 37 p. [In Ukrainian]

Grinnell J. 1917. The Niche-Relationships of the California Thrasher. Auk 34(4): 427-433. DOI: $10.2307 / 4072271$

Ignatov M.S., Ignatova E.A. 2004. Moss flora of Middle Part of European Russia. Vol. 2. Fontinalaceae-Amblystegiaceae. Moscow: KMK Scientific Press Ltd. P. 609 944. [In Russian]

Kurnaev S.F. 1973. Forest vegetation zoning of the USSR. Moscow: Nauka. 203 p. [In Russian]

Kurnaev S.F. 1980. Shadow broad-leaved forests of the Russian plain and the Urals. Moscow: Nauka. 316 p. [In Russian]

Mateo R.G., Vanderpoorten A., Muñoz J., Laenen B., Désamoré A. 2013. Modeling Species Distributions from Heterogeneous Data for the Biogeographic Regionalization of the European Bryophyte Flora. PLOS ONE 8(2): e55648. DOI: 10.1371/journal.pone.0055648

Popov S.Yu. 2016. The climatic patterning of Sphagnum sect. Sphagnum species distribution in the East European Plain. Arctoa 25(2): 332-352. DOI: 10.15298/arctoa.25.26

Popov S.Yu. 2017. Modeling the species distribution range using geostatistical techniques (example of Sphagnum mosses). Transactions of Karelian Research Centre of Russian Academy of Science 6: 70-83. DOI: 10.17076/ bg558 [In Russian] 
Popov S.Yu. 2018. Distribution pattern of seven Polytrichum species in the East European Plain and Eastern Fennoscandia. Botanica Pacifica 7(1): 25-40. DOI: 10.17581/bp.2018.07108

Popova N.N. 2002. Bryoflora of Middle Russian Uppland. I. Arctoa 11: 101-168. [In Russian]

Silaeva T.B., Chugunov G.G., Kiryukhin I.V., Ageeva A.M., Vargot E.V., Grishutkina G.A., Khapugin A.A. 2011. Flora of the National Park «Smolny». Mosses and vascular plants: annotated list of species. Moscow: Com- mission of RAS for the Conservation of Biological Diversity. 128 p. [In Russian]

Söderström L. (Ed.) 1998. Preliminary distribution maps of bryophytes in Northwestern Europe. Vol. 3 (Musci J-Z). Trondheim: Mossornas Vónnar. $72 \mathrm{p}$.

Tolmachev A.I. 1974. Introduction to Plant Geography. Leningrad: Publisher of the Saint Petersburg State University. 243 p. [In Russian]

Vtorov P.P., Drozdov N.N. 2001. Biogeography. Moscow: VLADOS-PRESS. 304 p. [In Russian]

\title{
PACПРОСТРАНЕНИЕ PTILIUM CRISTA-CASTRENSIS HA TEPРИTOРИИ ВОСТОЧНО-ЕВРОПЕЙСКОЙ РАВНИНЫ И ВОСТОЧНОЙ ФЕННОСКАНДИИ
}

\author{
С. Ю. Попов*, Ю. А. Макуха \\ Московский государственный университет имени М.В. Ломоносова, Россия \\ *e-mail:s_yu_popov@rambler.ru
}

Ptilium crista-castrensis является одним из наиболее распространенных видов в лесной зоне. Он является обычным видом мохового яруса в черничных лесах. В небольших количествах он может произрастать почти во всех типах леса, даже на болотах и лугах. Он также является компонентом мохового яруса в сообществах тундры. На основе сведения литературных источников с аннотированными списками локальных бриофлор в единую географическую базу данных, построена карта модельного apeала P. crista-castrensis методом кригинга. Всего было использовано 179 точек, среди которых 39 относится к заповедникам и национальным паркам. На основании наложения непрерывных покрытий встречаемости вида и климатических факторов установлены климатические предпочтения вида. Наложение модельной карты на карту растительных зон позволило провести анализ его пространственного распространения. На границе между лесной и степной зонами встречаемость P. crista-castrensis резко падает. На юге он становится довольно редким видом, растущим преимущественно в небольших массивах сосновых насаждений. В открытой степи этот вид исчезает. Максимум его встречаемости приходится на подзону Северной тайги. Здесь находится климатический оптимум вида. В численных значениях климатический оптимум соответствует годовой температуре около $-1^{\circ} \mathrm{C}$ и влажности воздуха около $80 \%$. В лесной зоне P. crista-castrensis имеет встречаемость от спорадической до широкой. Наихудшими климатическими условиями для P. crista-castrensis на севере являются низкие температуры и низкое количество осадков, несмотря на высокую влажность воздуха. На юге он перестает расти из-за высоких летних температур и низкого количества осадков.

Ключевые слова: ареал, биогеография, встречаемость вида, климатический оптимум вида, методы геостатистики 